\title{
Brazilian Municipal Public Social Security Systems: Determinant Variables of Their Financial Result
}

\author{
Wendel Alex Castro Silva ${ }^{1}$, Lamartine Pereira Baeta Filho ${ }^{1}$, Elisson Alberto Tavares Araújo ${ }^{1} \&$ \\ Christian Moisés Tomaz ${ }^{1}$ \\ ${ }^{1}$ Faculdade Novos Horizontes, Brazil \\ Correspondence: Christian Moisés Tomaz, Faculdade Novos Horizontes, Brazil. E-mail: \\ christian.tomaz@live.com \\ Received: March 10, 2015 \\ Accepted: April 10, 2015 \\ Online Published: May 25, 2015 \\ doi:10.5539/ibr.v8n6p1 \\ URL: http://dx.doi.org/10.5539/ibr.v8n6p1
}

\begin{abstract}
The performance of the Brazilian civil servants' social security system is an important element for the proper functioning of the Brazilian public finances. This paper's goal is to identify the variables that condition the defrayal and the financial deficit of municipal public servants' welfare regimes (RPPSs), in Brazil. To achieve it, we carried out a survey with the managers of these RPPSs, and obtained 84 answers. A multiple regression with the stepwise method was applied in the data analysis, in order to identify the main variables that explain the deficit. It was found that the financial balance, the number of servants who are members of the system, and the value of the monthly contribution granted by the employer entity were responsible for the deficit. It was concluded that there is an imbalance between the estimated amount of contributions and the volume of benefits actually paid by the RPPSs. Still, may achieve or improve the surplus, from the improvement of those variables that have conditioned the negative results.
\end{abstract}

Keywords: civil servants, social security system, public finances, municipalities, Brazilian public finances

\section{Introduction}

The Brazilian municipal civil servants' social security system has a strong impact on the public finance management, is one of the most sensitive areas in this finance accounts, and is relevant to the improvement of Brazilian Public Administration (PA). The municipalities that have an own social security regime (RPPS) face the challenge of improving efficiency in cost $\mathrm{x}$ benefit ratio of these finances.

The Brazilian Constitutional Amendment (EC) n 20/98 (the so-called "Reform of the social security system), along with the Brazilian Federal Law no 9.717/98 (the "General Law of the Public Social Security System"), introduced structural changes in the social security system of all civil servants of the Union, the states, the Federal District and the municipalities (the Brazilian federated political entities), defining the RPPS with the explanation of its contributory characteristics and its need for financial and actuarial balance. The organizations that manage those systems are the pension funds. The system has a financial accumulation phase, when resources are collected from workers and their employers (public agencies and entities). Later, there is the stage of payment of benefits, when the beneficiary fulfills the conditions that enable him or her to receive the monthly pension. All this brought a greater transparency to the defrayal of the RPPS, turned mandatory the contributions, and limited the participation of the State in this defrayal.

The Reform changed the relationships between the different spheres of Government regarding the management of social security systems. Prior to this General Law, the states, the Federal District and the municipalities had autonomy on the parameters to structure their own regimes, since respected the constitutional precepts. From the promulgation of the Law, more criteria of balancing these parameters were established, involving risk management, assets and liabilities, and overcoming of actuarial targets.

The development of a balanced social security system using the allocation model, under the administration of the State, is organized from contributions from workers and employers of the economically active population, in most economies that adopt it.

With that, the modern State introduced the implicit risk associated with this system. That risk may be connected to the imbalance between the amount of contributions expected and the amount of payments (benefits). And it 
can arise from the change in the variables that are outside the direct control of the State and pension systems (Tafner \& Giambiagi, 2007). According to Delgado, Querino, Rangel, and Stivali (2006), the introduction of implicit risk is a form of social protection to prevent disabling risks from the work, being necessary to face the risks related to age and conditions of life of the insured persons.

According to Tafner and Giambiagi (2007), in Brazil the social security system has been a tough fiscal constraint factor, having achieved deficits of about 5\% of the Gross Domestic Product (GDP) in 2006, putting the country in the group of the largest social security deficits in the world. According to data from the Ministry of Social Security, in 2013 the expenditure on benefits of RGPS represented 7.5\% of Brazil's GDP. The net revenue was responsible for $6.4 \%$ of the GDP, and the need for funding reached $1 \%$ in this same period.

In this context, personnel expenses represent a significant portion of the public service defrayal. The amount of payment to retired servants grows faster than the contributions made by the working servants, indicating that, in the short term, the cost of payments to retired people and pensioners exceed the workers' contributions, which may cause loss in the benefits for the servants and the failure of the system. Such a framework suggests the inefficiency of the State in managing the system.

By now, of the 2,207 municipalities that created their own RPPSs, 331 have extinguished them and joined the federal National Social Security Institute (INSS). A hundred other systems may fail, and 700 more have pending issues in the Ministry of Social Security and Welfare (MPAS, 2011) and may face the suspension of voluntary resources transfers from the Federal Government. Thus, this research's subject surely is relevant, as there is a need to investigate the financial situation of the Brazilian municipal civil servants' RPPSs, and to identify the factors that have been causing that financial imbalance in the municipalities

The question that guides this study is: what are the variables conditioning the financial result of Brazilian municipal civil servants' RPPSs?

\section{Theoretical Framework}

\subsection{Social Security in Brazil}

A social security system can be organized as a system of capitalization, or by allocation or as a mixed model. In the capitalization mode, the active workers' contributions constitute a holding fund that will be the basis for their future benefits. In the second one, the workers are financial backers of the retirees (Kreter \& Bacha, 2006). In the mixed mode, there is a combination of the two preceding systems.

To Giambiagi and Além (2000), with the promulgation of the Brazilian Federal Constitution in 1988, the Brazilian social security system got most of its current ruling and its current profile as the General Social Security System (RGPS). The former INPS (National Welfare Institute) was transformed into the current National Social Security Institute (INSS), now relieved from the responsibility on the management of the public health care system (which was managed by one of its branches, the former National Institute of Medical Assistance - INAMPS), and kept the allocation mode in the current system.

Unlike other countries that have carried out reforms in their social security systems (migration of regimes), in Brazil, the changes were made seeking the financial viability of the allocation system, due to fiscal constraints and the high cost of transition to the system of capitalization (Almeida \& Cruz, 2008).

\subsection{Public Security System}

According to Pierre (2005), the world has experienced conflicts because of the changes Governments try to make in the public social security system. France is one of the most recent examples. In that country, there is no supplementary social security system as in Brazil. Pension insurance reform implemented in 2010 came in order to harden the conditions for pensions to be granted. And because of the increase in life expectancy (the proportion of people above 60 years old exceeds $20 \%$ of the whole population) the age to qualify for receiving pension is now 67 years old, without discount. In the United Kingdom, the private social security plans grant defined benefits. England has a system that covers a fixed benefit based on a credit depending on the income level and on the basis of the salary and wage average revaluation during the life. In the United States, the system has a progressive benefit formula, based on lifelong earnings. Australia has a system anchored in retirement incomes, a benefit by age paid with public revenues. It is a defined benefit system, also adopted in Japan.

In Brazil, the social protection of the public servant has evolved from a welfare system (Tavares, Ibrahim, \& Varma, 2004). Castro and Lazzari (2002) mention that law No. 8.162/91 settled the federal public servant's contribution to the Servants' Social Security Plan (PSSS) - created by law No. 8.112/90. The Federal Constitution of 1988 did not determine the participation of those servants in defraying their retirements and the 
pensions for their dependents.

The Constitutional Amendment No. 20/98 determined the criteria for the civil servants' participation in the defrayal of RPPSs maintained by agencies and other federative entities. These criteria were preserved by the Constitutional Amendment $\mathrm{n}^{\circ}$ 41/2003, with additional ruling for the defrayal and the granting of benefits. The Law $\mathrm{n}^{\circ}$ 9.717/98 ratified the contributory character of the social security systems foreseen in the Constitution of 1988 , and in addition limited the coverage of these systems with respect to the universe of beneficiaries and the list of benefits (Brazil, 2002).

\subsection{Social Security Deficit and Conditioning Variables}

About the social security deficit, some claim to be the total amount of money collected by the system lesser than that spent on benefits. On the other hand, some believe there is no deficit, and that the values collected extrapolate the defrayal cost. But there is a consensus on the issue of the deficit in three bodies of opinion, namely: the constitutionalist, the fiscal and the pragmatic (Vaz, 2009).

Stiglitz (2000) points out that, due to the characteristics of the public servants' system regime, its deficit reached the largest magnitude in the mid-1990s.

Giambiagi and Além (2000) when referring to the reform of the system and the risk of transactional deficit, state that the retirement systems have emerged as capitalization schemes, without strict rules that prevented against some practices. The combination of small number of retirees and the accumulation of money in the systems' accounts generated two types of addictions: the first is the adoption of "generous" rules of retirement without an actuarial revaluation and plans; the second is the embezzlement of resources.

Tafner and Giambiagi (2007) assert that social security systems, [...] have important properties, such as its own rules that determine their behavior. However, since they communicate with systems that are independent, are affected by them. So, they depend not only on his own conditions, but also the conditions of other systems, i.e. the variables that determine the conditions of them.

\subsection{Actuarial Calculation}

The actuarial calculation aims to measure the intrinsic risk to the uncertainty of events which cause social security operational expenses, and, as a result, to establish contributions revenues that allow the balance of cash flow, in long term, to all citizens covered by the plans of benefits (Conde \& Ernandes, 2007).

According to Vilanova (1969), the actuarial risk is the consequence of the unexpected increase in the responsibilities of the benefit plan, a factor represented by mathematical reserves in more intense pace than the one expected for the growth of the guaranty resources. There are several reasons, such as: the insufficiency of the rate of return on investments versus the actuarial rate, the inadequacy of the biometric table, the high real increase in the Board wages, the decrease in social security benefits and the imbalance intrinsic to writing down the ruling of the benefit plan. That risk refers to the discrepancy between the actuarial assumptions adopted in the calculation of benefits, contributions, technical provisions and the data actually practiced (Vilanova, 1969).

The actuarial deficit is the difference between the social security system's revenue and its expenses over the period while the servant and its dependents are linked to the regime. This deficit happens when there is application of outdated rules, along with the difficulty of getting new sources of funding, preventing from achieving the stabilization of social security accounts of the federated entities. These deformities cause high deficits in the RPPSs, hindering the public finance management. The deficit arises when the value of the reservation realized by the servants' contribution, summed to the patrimony of the fund is insufficient to ensure that all participants - active, inactive and dependent - receive retirements and pensions. In short, the fund has a greater obligation to its contributors than the value that is being accumulated to cover the payments (Brazil, 2002).

The RPPS is a system of allocation which, although not of capitalization, is guided by principles of actuarial balance. The contribution percentage over the salaries is estimated so that the expected current value of the flow of contributions, along the active lifetime of the contributor, is equal to the expected current value of the flow of benefits received after he/she becomes inactive. The financial balance of a simple allocation system basically depends on the ratio between contributors and beneficiaries, but has been influenced, unfavorably and slightly, by the reduction in the birth rate and increase in lifetime expectancy of the population, resulting in a lengthening of the period of entitlement of benefits, and by the increase in the informal job market. So, the contribution rates have been insufficient (Ogasavara, 1998).

For Cardoso et al. (2004), whether by regulatory requirement or by demand of the diagnosis and monitoring of 
the domestic social security systems, it is important that periodic technical analysis are carried out for the continuous management of their elements of economic-financial balance.

The largest imbalance of countries' public finances comes from the way the social security system is funded. The system's financing potential, almost all over the world, suffers from demographic changes (Ellery Jr. \& Bugarin, 2003). For Bogoni and Fernandes (2011), the imbalance stands out among the structural bottlenecks of the public accounts. Giambiagi, Zylberstajn, Afonso, Souza, and Zylberstajn (2007) point out that the "social security problem" is associated with the ageing of the population, because the retirement ruling, formerly suitable, has become incongruent to the demographic scenario. This stems from the weak evolution of gross domestic product (GDP), in the last two decades, the increases in minimum wage and early retirements, in addition to the expansion in the number of elderly. In this sense, according to Zylberstajn, Zylberstajn, Afonso, and Souza (2008), the main variable that explains the system's spending is the proportion of elderly.

Izerrougene (2009) argues that the State intervention should occur in the arbitration between maintaining a satisfactory degree of retirements and stabilizing the rates of contribution. Among the measures adopted by other countries to reduce the social security expenses, there was a decrease of the basis of calculation of retirements (developed countries) and expansion of the age to retire (United States, Germany and England).

Brazilian spending with the social security system becomes larger if related to GDP or in comparison to those of other countries (Leite, Ness, Jr., \& Klotze, 2010; Bogoni \& Fernandes, 2011). Also, the financial deterioration of the social security systems stems from the embezzlement of resources for electoral purposes, mismanagement and excessive costs (Simão, 2010), and by factors endogenous to the monitoring of the RPPSs.

\subsection{Public Governance - Public Sector (GSP) and Agency Problem}

In Latin America, public governance is based on aspects that include both studies on public policy and the process of democratization as the administrative machine management models (Andion, 2012). In Brazil, the public administration has been changed since the intense debate about the crises of governance and credibility of the States of Latin America in the decades of 1980 and 1990 in relation to more stable economies (Paes de Paula, 2005). Since then, it was devised instruments based on the political and developmental perspective, and having as a pillar the culture of corporate entrepreneurship to the deepening of the current reforms.

According to Bresser-Pereira (1998), the main objective of public administration would be strengthening the strategic core of the government, in the cultural and managerial dimension, in that it reduces a whole bureaucratic apparatus, and making more flexible the system of stability for the public servants (Bresser-Pereira, 2005). Among the activities of a competitive nature, it would be the social and scientific services. Thus, even the welfare system, the social security, as well as education and health should be professionalized through the use of results management practices.

On the other hand, the increased managerial aspect in public administration has been directed to a constant debate about the Agency problem, due to the needs of different interest groups in the process of decentralization and social emancipation (Farah \& Barbosa, 2001; Paes de Paula, 2005). On this regard, in the midst of a plurality of interests, in that it extends the involvement of the various social actors in the construction of the new public management model, in addition to the institutional question, it has been seeking a greater understanding of how governments should, indeed, be administered (Denhardt, 2011). This is, fundamentally, to deal with the dichotomy between the social pact and the political and cultural problems (Capobiango, Nascimento, Silva, \& Faroni, 2013) that influence the management of the administrative machine.

As for the pillars of the administrative reform project, it was considered the prospect of governance whose purpose is to increase the efficiency and effectiveness of governmental actions. It is worth mentioning three dimensions (Paes de Paula, 2005) critical to the structural balance: the sociopolitical, the institutional and the financial-economic dimensions. The latter comes from the core of strategies represented by ministries, and industry and executive chambers (Diniz, 2000). So, their decisions produce effects in all instances of Government (States and municipalities).

Besides allowing the decentralization of the State apparatus (Kickert, Klijn, \& Koppenjan, 1997; Denhardt \& Denhardt, 2003, Denhardt, 2011), the Public Sector governance (GSP) is pervaded by the increasing participation, transparency and accountability (Cunha, Duclós, \& Barbosa, 2006). This movement has been strongly influenced by countries, such as Germany, where, under the political-developmental optics, it was sought to enhance structural aspects such as management, transparency, accountability and legality of the Public Sector (Kissler \& Heidemann, 2006). In this managerial perspective, the GSP is associated with public transparency and, especially, the accountability about the society's resources that are managed by the 
Government in all areas.

According to Frey (2007), the Public Administration management model uses the managerial practice ordinarily used in private companies, trying to apply enterprise management mechanisms to the governmental sector. This transposition of managerial models from the private to the public area-theory of Managerialism-is one of the foundations of the New Public Management-NGP (Ferli, Ashburner, Fitzgerald, \& Pettigrew, 1996; Denhardt, 2011), which advocates for efficiency results or the focus on the customer (Bresser-Pereira, 1997). In addition, corporate governance elements should be added to the Public Administration (Cunha, Duclós, \& Barbosa, 2006). This is a set of controls and incentives to prevent or resolve bottlenecks in an environment of political risk and uncertainties.

As public managers are aware of an informational content of which the taxpayers (owners) are unaware, setting up an informational asymmetry which generates a disadvantage in achieving the public interest (Akerlof, 1970). Thereby, the public governance becomes an essential role as guarantor of public transparency, because it enables a better monitoring on public agents.

On the other hand, the literature has highlighted the fragility of local governments, whether of the executive, whether from the legislative power. There are also patrimonial bases present in the municipal governments (Kuschnir, 1993; Lopez, 2004; Raupp \& Pinho, 2013). In the case of local pension funds, the main problems would be related to the administrative structure, the revenue scaling problems, the management capacity, the distributive nature of the income, the characteristics of each municipality, and also the political process and the Party alliances. It is possible to examine relevant aspects to imbalance of RPPS considering the analysis of the determinants of the social security system deficit as an indicator of ethical attitude, on the one hand, and, more explicitly, the problems concerning the organization and sustainability of these funds, on the other hand.

\section{Methodology}

This paper has an empirical-descriptive and quantitative characteristic (Collis \& Hussey, 2005). Its goal is to identify the conditioning variables of the financial result of RPPSs of municipal public servants in Brazil. As the topic of public security in Brazil has been little studied, the scientific research found was limited.

The multiple regression analysis detailed ahead was applied herein. The analysis units were the Brazilian municipalities that have RPPS, and the observation units were their accounts and their representatives in these municipalities.

For the composition of the sample, we used the probabilistic method for convenience (according to the availability of data), and by judgment (in the interest of the researcher) (Hair Jr., Black, Babin, Anderson, \& Tatham, 2009), in order to obtain data from the largest possible number of municipalities. It should be noted that the resulting bias of this method was diluted because we sought to work with municipalities from all Brazilian states. Thus, the results would significantly mirror the population. The eligibility criterion was: municipalities that had RPPS.

On the website of MPAS there were data on the amount of federal entities subject to each type of security scheme: RGPS, RPPS and RPPS in process of extinction. For each unit of the Federation, the information from the State Government, the capital city and the municipalities were recorded. At the end of 2008, the 26 States, the Federal District, the 26 state capital cities and 1,852 municipalities had RPPSs for their active and inactive servants, and pensioners (MPAS, 2011).

On that site, it was identified the electronic address (email) of the representatives of the RPPSs of the municipalities, from a link in which they should inform, in the formulary "Social Security Statement", the monthly contributions transferred to the RPPS, balances, number of servants, contributions rates, among others. In addition, there was the name of the manager of the RPPS and his/her email address.

After the collection of these addresses, a descriptive exploratory survey was carried out, which is applied in the preliminary steps of the study of a phenomenon, with the goal of anticipating the perception about a topic and provide the basis for a deeper research, or when there are no models and concepts to be measured on the phenomenon, the best way to measure it or unravel new facets about it (Forza, 2002). This occurred with the sending of structured pilot questionnaire, via email, to the five municipalities, containing eight questions about the socio-economic situation of the Mayors and the managers of RPPSs, to validate it. After detecting that it served the purposes of the survey, with some adjustments, the final version was submitted to the managers of RPPSs of 1,852 municipalities, between May and August, 2011. Of this total, there was the return from 84 municipalities. Since missing data (missings) did not exist in the responses, they all had their information analyzed. Therefore, it is emphasized that the sample of this study follows the criteria acecibilidade, highlighting 
also that corresponds to approximately $5 \%$ of the population.

From the responses of these entities, in which the RPPSs were legally established until August 30, 2011, it was carried out a documentary research on the information present in documents completed and made available by the surveyed organizations, and on the remaining data about the variables listed in Table 1 (below), on the site of the MPAS.

It should be noted that some reasons reported by RPPSs managers not to respond to the questionnaire were: lack of time, non-authorization by the Mayor to provide the requested information, did not consider himself/herself the most suitable person to answer it, among others.

In the analyses, the data descriptive research and Spearman correlation tests were carried out to check the existence of a linear relationship between the ratio deficit/superavit of RPPSs and other variables (Table 1) and its intensity. Then it was applied a multiple regression analysis to identify the variables conditioning the deficit. The significance level adopted was $5 \%(\alpha=0.05)$ to consider the statistically significant results. There was evidence when the $\mathrm{p}$-value was less than $0.05(\mathrm{p}$-value $<\alpha)$, and there were indications when $\mathrm{p}$-value was $<0.10$ (Neter, Kutner, Wasserman, \& Nachtsheim, 1996).

\subsection{Variables and Regression Model}

In the application of the multiple regression analysis, the dependent variable of the RPPS financial balance (SF) was its ratio Deficit/Superavit (DS), whereas the thirty independent are the ones shown in Table 1. It is assumed that the deficit-related risks are inherent to factors related to the characteristics of each municipality; it may also be considered structural factors that would affect the performance of these systems. In addition to these there are those factors considered strategic, and linked to the organization of the system. In this sense, the analysis of the variables related to DS is exploratory.

Table 1. Variables used in the study

\begin{tabular}{|c|c|c|c|}
\hline Variable & Description & Code & Description \\
\hline \multicolumn{4}{|r|}{ Dependent Variable } \\
\hline DS & $\begin{array}{l}\text { Deficit/Superavit of the } \\
\text { management office }\end{array}$ & RPPS & Value of deficit (-) or superavit (+) of the RPPS management office \\
\hline \multicolumn{4}{|r|}{ Independent variables } \\
\hline \multicolumn{4}{|c|}{ Characteristics of the municipalities } \\
\hline \multirow{5}{*}{ RG } & \multirow{5}{*}{ Geographic Region } & 0 & South \\
\hline & & 1 & Southeast \\
\hline & & 2 & North \\
\hline & & 3 & Northeast \\
\hline & & 4 & Central West \\
\hline \multirow{4}{*}{ POP } & \multirow{4}{*}{ Population } & 0 & Up to 100 thousand inhabitants \\
\hline & & 1 & From 100 up to 500 thousand \\
\hline & & 2 & From 500 up to 1 million \\
\hline & & 3 & Over 1 million inhabitants \\
\hline \multirow{2}{*}{ SEXCE } & \multirow{2}{*}{ Mayor's sex } & 0 & Female \\
\hline & & 1 & Male \\
\hline \multirow{2}{*}{ PCEX } & \multirow{2}{*}{ Mayor's profession } & & Public servant \\
\hline & & 1 & Businessman, private employee or self-employed \\
\hline \multirow{3}{*}{ ECEX } & \multirow{3}{*}{ Mayor's level of education } & 0 & Elementary school or less \\
\hline & & 1 & High school, complete or incomplete \\
\hline & & 2 & College \\
\hline
\end{tabular}




\begin{tabular}{|c|c|c|c|}
\hline \multirow{3}{*}{ EXPE } & \multirow{3}{*}{ Mayor's experience in public service } & 0 & Time of experience less than or equal to 1 year \\
\hline & & 1 & Time of experience greater than 1 year and less than 5 years \\
\hline & & 2 & Time of experience more than 5 years \\
\hline \multirow{13}{*}{ PPOL } & \multirow{13}{*}{$\begin{array}{l}\text { Political Party to which the Mayor is } \\
\text { affiliated }\end{array}$} & 0 & PSDB \\
\hline & & 1 & PMDB \\
\hline & & 2 & PT \\
\hline & & 3 & РTB \\
\hline & & 4 & PDT \\
\hline & & 5 & PV \\
\hline & & 6 & PP \\
\hline & & 7 & PPS \\
\hline & & 8 & DEM \\
\hline & & 9 & PR \\
\hline & & 10 & PSB \\
\hline & & 11 & PSC \\
\hline & & 12 & $\mathrm{PC}$ do B \\
\hline \multicolumn{4}{|c|}{ Characteristics of the RPPSs } \\
\hline \multirow{2}{*}{ FJUR } & \multirow{2}{*}{ Legal form of the RPPS } & 0 & Autarchy \\
\hline & & 1 & Fund \\
\hline \multirow{2}{*}{ CPRE } & \multirow{2}{*}{ Social Security Councils } & 0 & Active \\
\hline & & 1 & \\
\hline NSAT & Active servants & - & Number of active servants who are members of the RPPS \\
\hline NSAP & Inactive servants & - & $\begin{array}{l}\text { Number of retired servants and pensioners who are paid by the RPPS } \\
\text { management office }\end{array}$ \\
\hline AEE & $\begin{array}{l}\text { Contribution rate required for the } \\
\text { entity }\end{array}$ & - & $\begin{array}{l}\text { Regular rate plus the supplement required by the actuary for the entity on the } \\
\text { effective servants' payroll }\end{array}$ \\
\hline AEP & $\begin{array}{l}\text { Contribution rate practiced by the } \\
\text { entity }\end{array}$ & - & $\begin{array}{l}\text { Regular rate plus the supplement practiced by the entity on the effective } \\
\text { servants' payroll }\end{array}$ \\
\hline DIFA & Difference between rates & - & Difference between the rates required and practiced by the entity \\
\hline \multirow{2}{*}{ SGE } & \multirow{2}{*}{ RPPS manager's sex } & 0 & Female \\
\hline & & 1 & Male \\
\hline \multirow{2}{*}{ PGE } & \multirow{2}{*}{ RPPS manager's profession } & 0 & Public servant \\
\hline & & 1 & Businessman, private employee or self-employed \\
\hline \multirow{3}{*}{ NEG } & \multirow{3}{*}{ RPPS manager's level of education } & 0 & Elementary school or less \\
\hline & & 1 & High school, complete or incomplete \\
\hline & & 2 & College \\
\hline \multirow{2}{*}{ CAPG } & \multirow{2}{*}{ RPPS manager's qualification } & 0 & Qualified with CPA-10 (Note 1) \\
\hline & & 1 & Not qualified with CPA-10 \\
\hline FAP & Payroll & - & Monthly value of the entity's active servants payroll. Calculation basis in reals. \\
\hline RECE & $\begin{array}{l}\text { Revenue from the entity's } \\
\text { contributions }\end{array}$ & - & $\begin{array}{l}\text { Monthly value of revenue from social security contributions paid by the } \\
\text { employer entity, in reals }\end{array}$ \\
\hline RECS & $\begin{array}{l}\text { Revenue from the servants' } \\
\text { contributions }\end{array}$ & - & $\begin{array}{l}\text { Monthly value of revenue from social security contributions paid by the } \\
\text { servants, in reals }\end{array}$ \\
\hline
\end{tabular}




\begin{tabular}{|c|c|c|c|}
\hline RTC & Total revenue from contributions & - & RPPS management office's total revenue from contributions \\
\hline RECF & Financial income & - & Monthly revenue from financial investments in reals \\
\hline $\mathrm{AP}$ & Financial contribution & - & $\begin{array}{l}\text { Value of the monthly contribution for the coverage of the benefits granted by } \\
\text { the entity before the creation of the RPPS, in reals }\end{array}$ \\
\hline SF & Financial balance & - & $\begin{array}{l}\text { Value of the financial balance at the date of the survey, in reals (in accounting } \\
\text { terms, represents the availabilities) }\end{array}$ \\
\hline PCAR & Receivable credits & - & $\begin{array}{l}\text { Receivable credits concerning installment payments of contributions not paid } \\
\text { by the entity, in reals }\end{array}$ \\
\hline ATO & Assets of the RPPS management office & - & Value of the assets of the RPPS management office, in reals \\
\hline FAP & Retirees and pensioners & - & Total monthly payroll of retirees and pensioners, in reals \\
\hline OB & Other benefits & - & $\begin{array}{l}\text { Total monthly expenditure on benefits related to illness aid, maternity leave } \\
\text { salary, family allowance and reclusion aid }\end{array}$ \\
\hline DA & Administrative expenditure & - & $\begin{array}{l}\text { Monthly total value of administrative expenditure of the RPPS management } \\
\text { office, in reals }\end{array}$ \\
\hline
\end{tabular}

Source: Prepared by the authors.

The generalized multiple regression model applied was (Hair Jr., Black, Babin, Anderson, \& Tatham, 2009):

$$
Y_{i}=\beta_{0}+\sum_{i=1}^{j} \beta_{i} X_{i j}+\varepsilon_{i j}
$$

In which (adapted):

$Y=$ Financial balance of $\operatorname{RPPS}_{i}$;

$\beta=$ parameters;

$X_{i j}=$ variables of the municipality $i$, during the period $j$;

$\varepsilon_{i j}=$ estimation error (residue).

The assumptions of the model were tested, namely: i) normality of the dependent variable; ii) amount of observations greater than that of independent variables; iii) absence of exact or approximate linear relationship between them. We opted for ordinary least squares estimators (MQO) because they are not biased. To identify signs of redundancy among the independent variables, their correlation matrix was checked. And the descriptive analysis of the dependent variable was carried out. The method applied for the selection of independent variables was the stepwise, which is indicated when there is a large number of explanatory variables, and selects only those that provide greater joint contribution to explain the dependent variable (Hair Jr., Black, Babin, Anderson, \& Tatham, 2009).

After the definition of the final model, the following tests were carried out: effect (checks the power and the effect of the sample for the t-Student testing of the significance of the variables included in the model) and size (examines the power and the effect of the Fisher's F-test, which assessed the general adjustment of the model) (Neter, Kutner, Wasserman, \& Nachtsheim, 1996).

The tabulation of the data was carried out using the 2007 version of Microsoft Excel®, and the analyses were made by using the version 16 of the Statistical Package for the Social Sciences ${ }^{\circledR}$ (SPSS). The power of the tests was calculated by G-Power, version 3.1.

\section{Results}

\subsection{Correlation between DS and Independent Variables}

The Spearman correlation test (r) was carried out between the value of the deficit/superavit (DS) of the RPPS and the explanatory variables. Its null hypothesis $(\mathrm{H} 0)$ is that the correlation is null. The variables are correlated when $\mathrm{H} 0$ is rejected, that is, $\mathrm{p}$-value $<\alpha$. The results are presented in Table 2: 
Table 2. Correlation between DS and the independent variables

\begin{tabular}{|c|c|c|c|}
\hline Variable & Description & Spearman's $r$ & P-value \\
\hline \multicolumn{4}{|c|}{ Characteristics of the municipalities } \\
\hline RG & Geographic Region of the municipality under research & 0.024 & 0.831 \\
\hline POP & Population & -0.699 & $0.000 *$ \\
\hline SEXCE & Mayor's sex & 0.116 & 0.292 \\
\hline PCEX & Mayor's profession & 0.077 & 0.489 \\
\hline ECEX & Mayor's level of education & -0.294 & $0.007 * *$ \\
\hline EXPE & Mayor's experience in public service & -0.039 & 0.727 \\
\hline PPOL & Political Party to which the Mayor is affiliated & -0.517 & $0.000 *$ \\
\hline \multicolumn{4}{|c|}{ Characteristics of the RPPSs } \\
\hline FJUR & Legal form of the RPPS & -0.181 & $0.099 * * *$ \\
\hline CPRE & Social Security Councils & -0.001 & 0.996 \\
\hline NSAT & Active servants & -0.698 & $0.000 *$ \\
\hline NSAP & Inactive servants & -0.795 & $0.000 *$ \\
\hline AEE & Contribution rate required for the entity & -0.317 & $0.003 * *$ \\
\hline AEP & Contribution rate practiced by the entity & -0.116 & 0.293 \\
\hline DIFA & Difference between rates & -0.253 & $0.020 * *$ \\
\hline SGE & RPPS manager's sex & -0.104 & 0.346 \\
\hline PGE & RPPS manager's profession & -0.363 & $0.001 * *$ \\
\hline NEG & RPPS manager's level of education & -0.426 & $0.000 *$ \\
\hline CAPG & RPPS manager's qualification & -0.12 & 0.277 \\
\hline FAP & Payroll & -0.713 & $0.000 *$ \\
\hline RECE & Revenue from the entity's contributions & -0.728 & $0.000 *$ \\
\hline RECS & Revenue from the servants' contributions & -0.715 & $0.000 *$ \\
\hline RTC & Total revenue from contributions & -0.727 & $0.000 *$ \\
\hline RECF & Financial income & -0.228 & $0.037 * *$ \\
\hline AP & Financial contribution & -0.254 & $0.020 * *$ \\
\hline SF & Financial balance & -0.34 & $0.002 * *$ \\
\hline PCAR & Receivable credits & -0.349 & $0.001 * *$ \\
\hline ATO & Assets of the RPPS management office & -0.38 & $0.000 *$ \\
\hline FAP & Retirees and pensioners & -0.793 & $0.000 *$ \\
\hline OB & Other benefits & -0.08 & 0.471 \\
\hline DA & Administrative expenditure & -0.331 & $0.002 * *$ \\
\hline
\end{tabular}

Note. *Significant at $1 \%$. **Significant at $5 \%$. ***Significant at $10 \%$.

Source: Research data.

When there was no statistical significance to the test, there was not a correlation between the dependent variable DS (deficit/superavit of the RPPS management office) and the independent variables, which occurred ing with nine of them: geographic region; Mayor's sex; Mayor's profession; Mayor's experience in public service; Social Security Councils; contribution rate practiced by the entity; RPPS manager's sex; RPPS manager's qualification, and other benefits.

For the other 21 independent variables, there were statistically significant associations with DS, showing mostly 
a sharp significance at $1 \%$. For those with significance at $1 \%$ or $5 \%$, there were statistical evidences of the occurrence of correlation; if the significance was at $10 \%$, only indications of this correlation were shown. The variables that showed significance are discussed below.

Among the characteristics of the municipalities, population presented moderate negative correlation with the value of the variable DS (-0.699), indicating that the increase in the population size reduces the value of the variable SF (increase in the deficit). The Mayor's level of education presented weak and negative relationship with DS (-0.294). So, for mayors with higher education degree, the DS is smaller (the deficit is larger). The Mayor's Political Party presented weak and negative relationship with the value of DS (-0.517). So, the more the mayors are affiliated to the parties closest to the PC do B (see PPOL in Table 1), the higher the deficit of the municipality's system.

Concerning the characteristics of RPPSs, their legal form signaled weak negative correlation (-0.181) with the DS, but provided only indications of occurrence of this relationship. There was moderate and negative $(-0.698)$ correlation between the number of active servants and the DS, and strong and negative (-0.795) in the case of the number of inactive servants. So, if the number of servants (active or inactive) increases, the DS decreases (increase in the deficit), and this becomes more pronounced when there is expansion of inactive. About the contribution rates, it was found weak and negative relationship (-0.317) between the contribution rate required for the entity, the difference between rates (-0.253), and the variable DS. It is assumed that the higher the value of these tax rates, the greater the DS (smaller deficit).

Concerning the RPPS Manager, there was moderate and negative relationship between the manager's profession $(-0.363)$ or manager's level of education (moderate and negative $=-0.426)$ with the variable DS. As to the manager's profession, when it is the case of a civil servant, the value of the DS is larger (smaller deficit). The higher his/her education level, the lower the value of the DS (greater deficit).

When it comes to payroll values (-0.713), revenue from contributions from the entity $(-0.728)$, revenue from contributions of the servants $(-0.715)$ and total revenue of contributions $(-0.727)$, in all cases the correlation the value of DS was moderate and negative with. So, the higher their values, the smaller values of DS, i.e., the increase in revenue is linked to the deficit reduction, and thus these are some of the variables responsible for the defrayal of the RPPSs. It is noteworthy that the monthly value of the entity's active servants payroll is the calculating basis that generates the value of the contributions, so the growth of the amount of this payroll expands the revenues from contributions and shrinks the deficit.

A weak and negative relationship was detected between financial income (-0.228), financial contribution $(-0.254)$, financial balance $(-0.34)$, value of receivables $(-0.349)$, assets of the RPPS management office $(-0.38)$ and administrative costs $(-0.331)$ with the value of the DS. So, the higher the values of these variables, the lower the values of the DS. That is, the growth of the deficit would be tied to the reduction in financial income, balance, receivables, assets, increase in monthly financial contribution and administrative expenditure. The value of retirees and pensioners (-0.793) showed strong and negative correlation with the DS. So, as the total monthly payroll of retirees and pensioners grows, the DS reduces (the deficit increases).

\subsection{Conditioning Variables of the RPPSs Financial Balance}

Table 3 presents the result of adequacy and efficiency of the cross-section multiple regression model obtained.

Table 3. Analysis of variance using ANOVA

\begin{tabular}{lccccc}
\hline & Sum of Squares & df & Mean Square & Test F & Sig.† P-value \\
\hline Regression & $1.74310 \mathrm{E}+20$ & 3 & $5.81033 \mathrm{E}+19$ & 134.16 & $\mathbf{0 . 0 0 0}$ \\
Residual & $3.50796 \mathrm{E}+19$ & 81 & $4.33082 \mathrm{E}+17$ & & \\
Total & $2.09390 \mathrm{E}+20$ & 84 & & & \\
\hline
\end{tabular}

Note. $\dagger$ Statistical significance at $1 \%$.

Source: Research data.

It was possible to verify, by means of ANOVA, which deals with the statistical significance of the model efficiency (whether it can or not be applied with explanatory purpose), that the final equation proved to be suitable for the explanation of the variance of the dependent variable. With statistical significance at $1 \%$, the null 
hypothesis (H0) that the coefficients of the model are void was rejected, indicating a good adjustment of the regression.

Also, it is important to point out the existence of outliers because they may influence the analyses, causing distortions in the results, for they are different from most of the observations that describe the sample. They make the points of the graph not to be so well distributed, this being the proper situation, in which they concentrate around zero. Thus, the existence of outliers may impair the data normality test, since it can decrease the average down or overestimate it. However, it is unlikely a system that has no outlier.

The graphics of residuals are presented in Figure 1 and indicate the existence of outliers, but have average equal to zero, with constant variance. Then there are some points a little distant from the others and they are more focused.

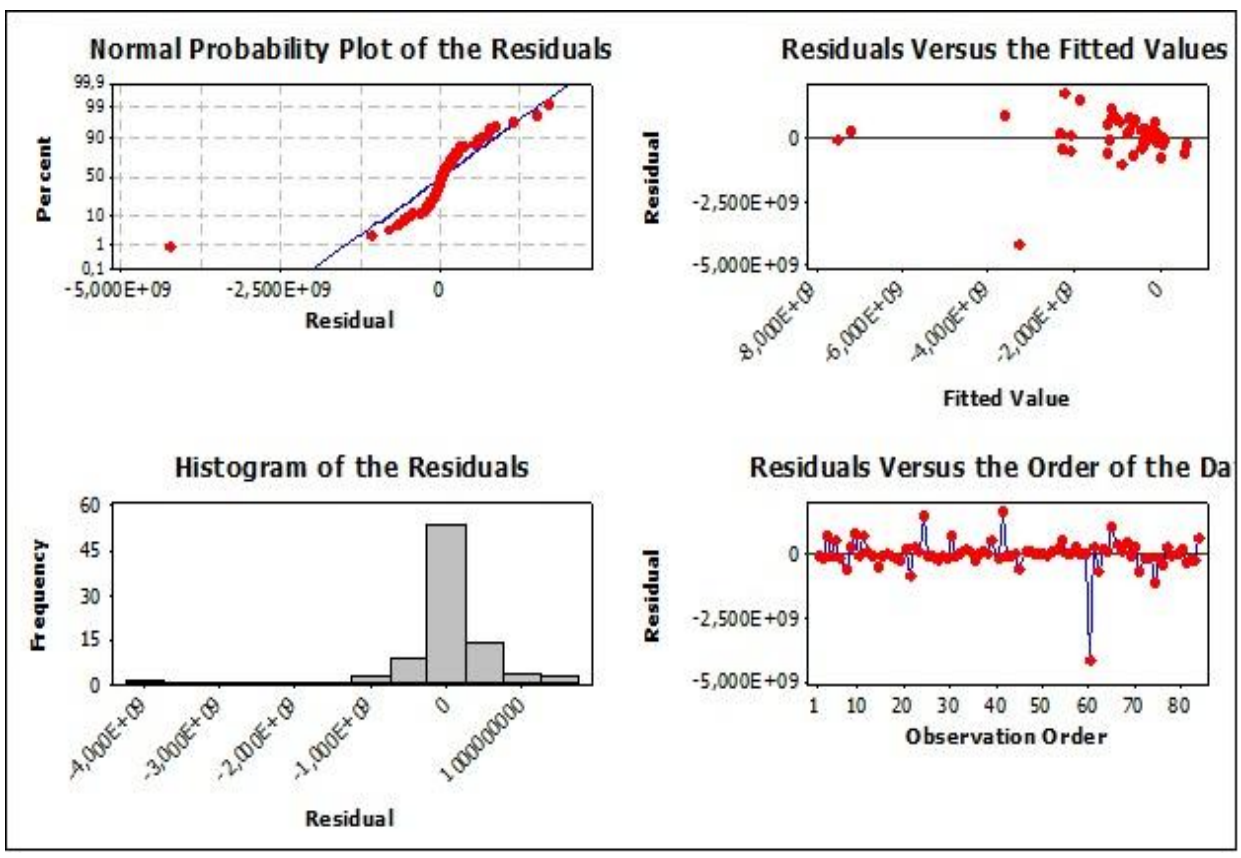

Figure 1. Residuals

Source: Research data.

After the definition of the final regression model, two tests were carried out: effect and size (Table 4). The first one was used to test the sample power and effect for the t-Student's tests that checked the significance of each of the variables included in the regression model. The second test was carried out for the power and effect of the Fisher's F test, which checked the general adjustment of the model.

Table 4. Statistical power of tests effect $\mathrm{e}$ size

\begin{tabular}{cccc}
\hline Test & N & Effect size & Statistical power \\
\hline Test t & 84 & $\mathrm{f}^{2}=0.16$ & $95 \%$ \\
Test $\mathrm{F}$ & 84 & $\mathrm{f}^{2}=0.21$ & $95 \%$ \\
\hline
\end{tabular}

Source: Research data.

The power of the tests was $95 \%$. The effect, due to the size of the sample, was 0.16 to average tests (t-test), and 0.21 for the F-test of variance analysis. These tests also validated the model, allowing for the analysis.

Table 5 presents the test for the coefficients of the variables that make up the final model. The tests present p-value less than the significance level (0.01), indicating that the three variables are required in the adjusted model. 
Table 5. Conditioning variables of the RPPSs' DS

\begin{tabular}{cccccccc}
\hline Independent Variables & $\begin{array}{c}\text { Estimation } \\
\text { Coefficients (B) }\end{array}$ & Statistical $\boldsymbol{t}$ & Sig. $^{\dagger} \mathbf{p}$-valor & $\mathbf{R}^{2}$ & Adjusted $\mathbf{R}^{2}$ & $\begin{array}{c}\text { Standard } \\
\text { deviation }\end{array}$ & $\begin{array}{c}\text { Durbin } \\
\text { Watson }\end{array}$ \\
\hline NSAT & -239.236 & -18.09 & $\mathbf{0 . 0 0 0}$ & & & & \\
AP & -268.22 & -4.67 & $\mathbf{0 . 0 0 0}$ & 0.837 & 0.862 & 1.321 & 2.022 \\
SF & 4.95 & 6.48 & $\mathbf{0 . 0 0 0}$ & & & & \\
\hline
\end{tabular}

Note. Dependent variable: Deficit/Superavit of the RPPS management office (DS); $\uparrow$ Statistical significance at $1 \%$.

Source: Research data.

Among the thirty independent variables used to check which ones would explain the DS of RPPSs in the municipalities, three were selected by stepwise method (includes and excludes each variable keeping in the final model those that together better explain the response variable), and all showed statistical significance at the level of $1 \%$. So, those that have not explained or explained very little of the variability of the DS were not included, and those who had a higher correlation with the value of the DS in the exploratory analysis were included, being the major determinants of their behavior. The variable financial balance (SF) was the one which revealed beta coefficient with positive sign, suggesting the possible existence of positive and significant relation between the DS and the balance of RPPSs. On the other side, the variables number of active servants members the RPPS (NSAT) and financial contribution (AP) presented beta coefficients with negative sign, signaling the likely existence of negative (or reverse) and significant relationship between the DS and these variables.

From Table 4, the final equation (Equation 2) obtained for explaining the DS was:

$$
D S_{i}=\beta_{0}-239.236 \mathrm{NSAT}-268,22 \mathrm{AP}+4,95 \mathrm{SF}+\varepsilon
$$

Then, the variable DS is a function of the three independent variables selected, being algebraically:

$$
D S=f(N S A T ; A P ; S F)
$$

The coefficient of determination of the model (R2) was equal to 0.862 , showing that the model was well-fitted, because $86.2 \%$ of the variability of the value of deficit/superavit are explained by the combined variability of the independent variables, which points out a pronounced explanatory power of the model. The Durbin Watson statistic was equal to 2.0217 , close to 2 , which shows a good fit. So, all the tests signaled positively, providing the indication that the results have statistical validity and can be analyzed, because they are representative of the sample.

The variable SF signaled that every increase of one unit in the value of financial balance causes the expansion of the deficit/superavit value of RPPS in 4.95. So, increasing the value of SF (of accounting availabilities-available financial resources, banks accounts transactions, financial applications of immediate liquidity, among others) reduces the value of the deficit (if the value is negative) or increases the superavit (if the value is positive). The NSAF variable in its turn suggested that every increase of one unit in the number of active servants linked to RPPS generates the decrease in the value of the DS of RPPS in 239.236. In this way, the growth in the number of active servants expands the value of the deficit. And, the variable AP indicated that every one unit increased in the value of the monthly contribution to cover the benefits causes the reduction of the value of the DS in 268.22. So, the increase in the value of the contribution value increases the deficit. These findings are in agreement with Stiglitz (2000), Giambiagi and Além (2000), and Giambiagi and Tafner (2007), for whom the social security situation has worsened.

The RPPSs have not complied with the determinations of the actuarial calculation and, apparently, the actuarial risk has been staying above the previously estimated, or, if properly projected, one has not been able to provide effective solutions to minimize it. With this, the desired financial balance in the cash flow has not been achieved, occurring disagreement between the amount of inputs and outputs of financial resources in the RPPSs of the municipalities surveyed, even with the enactment of the EC 20/98 and EC 41/2003 and Law 9.717/98, rules that sought to improve the existing social security models.

In addition, there are possibly agency problems and also contractual problems between the Public Administration and the managers of these RPPSs. As a result, agency and transactional costs may be increasing, helping to undermine the performance of the regimes. In this way, there is a need for an effective public governance, 
especially with accountability by the Public Administration and social control exerted by the servants and other citizens, who help the support of the public machine.

It must be emphasized that there is an imbalance between the estimated amount of contributions and the estimated amount of benefit payments in the RPPSs of municipal public servants. Thus, the total collected resources have been less than the total amount spent on the benefits, extending the inadequacy of the public finances.

\section{Final Considerations}

The central objective of this study was to identify the conditioning variables of the financial result of RPPSs of municipal public servants in Brazil.

The variables that presented statistically significant correlation with the increase in the deficit were: the municipality population; the Mayor's education level; the Mayor's political party; the increase in the number of active and inactive servants (mostly the inactive); the RPPS Manager's level of education; the reduction in the financial income, in the balance, in the receivable credits, and in the assets; the increase in the monthly contribution, and in administrative expenditure. Those which showed to be related to the reduction and therefore would be related to the defrayal of the RPPSs were: increase in contribution rates, increase of the values of the payroll of servants and of the revenue from contributions (paid by the public entity, the servants and total) and, still, the manager of the RPPS being a professional civil servant also seems to contribute.

The regression analysis showed that: i) the increase in the number of active servants expands the value of the deficit; ii) the growth of the value of the financial contribution expands the value of the deficit; iii) the increase in the financial balance value reduces the value of the deficit or increases the superavit.

The deficit of RPPSs has been shown to be a constant in Brazilian municipalities. So even existing simulations about the risks of the social systems' deficit, aimed at examining the impact of structural reforms in the economy, in the case of the replacement of the allocation system by the capitalization system, the risks (determining variables of the deficit) are several, and comprise the contributor's premature death and disablement, among others. When performing the actuarial calculation, it is pursued to measure the risk intrinsic to the uncertainty around the social security expenditure, which allows the establishment of revenues values that provide the balance of the regimes' cash flow for the coverage of benefits plans. However, the actuarial deficit is caused by the application of outdated rules, which make difficult obtaining new sources of funding, that could stabilize the social security accounts of the entities. The rates of contribution have been being insufficient, and the basic rates should be greater than those defined by the law. However, this could further burden the contributors and may become an unviable solution.

Finally, we conclude that the vast majority of the management offices of the RPPSs that composed the sample showed a deficit in their RPPS, which seems to be common among peers. Thus, it is seen a strong imbalance between the financial value that the office expects to receive from contributions and the value expected to be spent to pay the benefits to public servants. In this context, from the knowledge of the factors that have determined this imbalance, Government actions are necessary (efficient and effective public policies), otherwise there is the risk of the maintaining or worsening of this situation, which may undermine the financial sustainability of these entities, as well as of their servants.

As a contribution of this research to the Academy, we point out the exploration of an incipient theme in scientific researches in Public Administration, been identified here some variables that mostly have contributed to the occurrence of the municipal social security system deficit. But, also, it may be a basis for studies in other areas of knowledge such as demography and actuarial science. To the Public Administration and to the Government, it provides information that may assist in the development of positive public policies, and provide improvement in the institution, in planning and managing these RPPSs, enabling the reduction-maybe the elimination-of this deficit. Still, may achieve or improve the surplus, from the improvement of those variables that have conditioned the negative results. Also, to look for alternatives for financing the public social security and, who knows, foster and use private or complementary social security mechanisms, reducing the costs to the public entity and eliminate the deficit.

As limitation, we had difficulty in obtaining the responses from the RPPSs administrators. As a suggestion, we propose to carry out studies with samples larger than the ones we used, which might indicate other variables that could contribute to a better understanding of the topic and allow the improvement of the Brazilian Public Administration. 


\section{Acknowledgements}

The authors thank FAPEMIG (Foundation for Research of the State of Minas Gerais) for financial support.

\section{References}

Akerlof, G. (1970). The markets for lemons: Quality uncertainly and the market mechanism. The Quartely Jornal of Economics, 84(3). 488-500. Retrieved December 05, 2014, from http://staff.bath.ac.uk/ecsjgs/Teaching/Advanced\%20Microeconomics/Articles/akerlof.PDF

Almeida, R. M., \& Cruz, M. V. G. (2008). O regime próprio de previdência social no município: Estudo de casos em minas gerais. Anais do Encontro da Associação Nacional de Pós-Graduação e Pesquisa em Administração, Rio de Janeiro, RJ. Brasil, 32. Retrieved December 05, 2014, from http://www.anpad.org.br/admin/pdf/APS-B1025.pdf

Andion, C. (2012). Por uma nova interpretação das mudanças de paradigma na administração pública. Cadernos Ebape., 10(1), 1-19. http://dx.doi.org/10.1590/S1679-39512012000100003

Bogoni, N. M., \& Fernandes, F. C. (2011). Gestão de risco nas atividades de investimento dos regimes próprios de previdência social (RPPS) dos municípios do Estado do Rio Grande do Sul. Revista Eletrônica de Administração, 17(1), 117-148.

Brasil. (1981). Constituição da república dos estados unidos do Brasil. Brasília.

Brasil. (1998). Emenda Constitucional (EC) $n^{\circ} 20$, de 15 de dezembro de 1998. Dispõe sobre as noções gerais do sistema previdenciário brasileiro. Brasília: Senado Federal.

Brasil. (2002). Tudo o que você precisa saber sobre a previdência social. Brasília: MPAS/ACS.

Brasil. (2005). Constituição da República Federativa do Brasil: Texto constitucional promulgado em 5 de outubro de 1988. Brasília: Senado Federal, Subsecretaria de Edições Técnicas.

Bresser-Pereira, L. C. (1997). Reforma do Estado nos anos 90: Lógica e mecanismos de controle. Brasília: MARE, Cadernos MARE, n. 1.

Bresser-Pereira, L. C. (1998). Reforma do Estado para a cidadania: A reforma gerencial brasileira na perspectiva internacional. São Paulo: Ed. 34.

Bresser-Pereira, L. C. (2005). Instituições, bom Estado e reforma da gestão pública. Revista Eletrônica sobre a Reforma do Estado, n 1 , Mar-Mai.

Capobiango, R., do Nascimento, A., Silva, E., \& Faroni, W. (2013). Reformas administrativas no Brasil: Uma abordagem teórica e crítica. REGE Revista De GestãO, 20(1), 61-78. http://dx.doi.org/10.5700/issn.2177-8736.rege.2013.62000

Cardoso, S. C. P., Fontoura, F. R. S., Capelo Júnior, E., Rocha, A. S., Câmara, S. F., \& Batista, P. C. S. (2004). Um modelo de avaliação de obrigações previdenciais de regimes capitalizados de previdência na administração pública. Anais do Encontro de Administração Pública e Governança, Rio de Janeiro, RJ. Brasil, $\quad 1 . \quad$ Retrieved December 05, 2014, from http://www.anpad.org.br/diversos/trabalhos/EnAPG/enapg_2004/2004_ENAPG243.pdf

Castro, C. A. P., \& Lazzari, J. B. (2002). Manual de direito previdenciário. São Paulo: LTr.

Collis, J., \& Hussey, R. (2005). Pesquisa em administração: Um guia prático para alunos de graduação e pós-graduação (2nd ed.). Porto Alegre: Bookman.

Conde, N. C., \& Ernandes, I. S. (2007). Atuária para não atuários. São Paulo: Associação Brasileira das Entidades Fechadas de Previdência Complementar.

Cunha, M. A. V. C., Duclós, L. C., \& Barbosa, A. F. (2006). Institucionalização do e-governo como instrumento de legitimidade da governança eletrônica no setor público no Brasil, Chile e Peru. Anais do Encontro da Associação Nacional de Pós-Graduação e Pesquisa em Administração, Salvador, Bahia. Brasil, 30. Retrieved December 05, 2014, from http://www.anpad.org.br/enanpad/2006/dwn/enanpad2006-adic-2856.pdf

Delgado, G. C., Querino, A. C., Rangel, L., \& Stivali, M. (2006). Avaliação de resultados da lei do fator previdenciário (1999-2004). Brasília: IPEA. Retrieved December 05, 2014, from http://www.ipea.gov.br/portal/index.php?option=com_content\&view=article\&id=4329\%3Atd-1161-avaliac ao-de-resultados-da-lei-do-fator-previdenciario-1999-2004\&catid=308\%3A2006\&directory=1\&Itemid=1 
Denhardt, J. V., \& Denhardt, R. B. (2003). The new public service. serving, not steering. New York: M.E Sharpe.

Denhardt, R. B. (2011). Teorias da Administração Pública. São Paulo: Cengage Learning.

Diniz, E. (2000). Globalização, reformas econômicas e elites empresariais. Rio de Janeiro: Editora FGV.

Ellery Jr. R. G., \& Bugarin, M. N. S. (2003). Previdência social e bem estar no Brasil. Revista Brasileira de Economia, 57(1), 27-57. http://dx.doi.org/10.1590/S0034-71402003000100003

Farah, M. F. S., \& Barboza, H. B. (2001). Novas experiências de gestão pública e cidadania. Rio de Janeiro: FGV.

Ferli, E., Ashburner, L., Fitzgerald, L., \& Pettigrew, A. (1996). The new public management in action. Oxford: Oxford University Press. http://dx.doi.org/10.1093/acprof:oso/9780198289029.001.0001

Forza, C. (2002). Survey research in operations management: A process based perspective. International Journal of Operations \& Production Management, 22(2), 152-194. http://dx.doi.org/10.1108/01443570210414310

Frey, K. (2007). Governança urbana e participação pública. Revista de Administração Contemporânea-Eletrônica, $\quad 1(1), \quad$ 136-150. Retrieved December $\quad 05, \quad 2014$, from http://anpad.org.br/periodicos/arq_pdf/a_629.pdf

Giambiagi, F., \& Além, A. C. (2000). Finanças públicas: Teoria e prática no Brasil. Rio de Janeiro: Campus.

Giambiagi, F., Zylberstajn, H., Afonso, L. E., Souza, A. P. F., \& Zylberstajn, E. (2007). Impacto de reformas paramétricas na previdência social brasileira: Simulações alternativas. Anais do Encontro da Associação Nacional de Pós-Graduação e Pesquisa em Administração. Rio de Janeiro, RJ. Brasil, 31. Retrieved December $\quad 05, \quad 2014, \quad$ from http://www.anpad.org.br/ anpad/eventos.php?cod_evento=1\&cod_edicao_subsecao=280\&cod_evento_edic ao $=33 \&$ cod_edicao_trabalho $=7083$

Hair, Jr. J. F., Black, W. C., Babin, J. B., Anderson, R. E., \& Tatham, R. L. (2009). Análise multivariada de dados (6th ed.). Porto Alegre: Bookman.

Izerrougene, B. (2009). A macroeconomia da previdência social. Revista de Economia Contemporânea, 13(1), 31-46. http://dx.doi.org/10.1590/S1415-98482009000100002

Kickert, W. J. M., Klijn, E. H., \& Koppenjan, J. F. M. (1997). Introduction: A management perspective on policy networks. In W. J. M. Kickert, E. H. Klijn, \& J. F. M. Koppenjan (Eds.), Managing complex networks: Strategies for the public sector (pp. 1-14). London: SAGE. http://dx.doi.org/10.4135/9781446217658

Kissler, L., \& Heidemann, F. G. (2006). Governança pública: Novo modelo regulatório para as relações entre Estado, mercado e sociedade? Revista de Administração Pública, 40(3), 479-499. http://dx.doi.org/10.1590/S0034-76122006000300008

Kreter, A. C., \& Bacha, C. J. C. (2006). Avaliação da eqüidade da previdência no meio rural do Brasil. Revista de Economia e Sociologia Rural, 44(3), 467-502. http://dx.doi.org/10.1590/S0103-20032006000300006

Kuschnir, K. (1993). Política e mediação cultural: Um estudo da câmara municipal do Rio de Janeiro. Dissertação de mestrado. Universidade Federal do Rio de Janeiro, Rio de Janeiro, RJ., Brasil.

Leite, A. R., Ness Jr., W. L., \& Klotzle, M. C. (2010). Previdência social: Fatores que explicam os resultados $\begin{array}{lllll}\text { financeiros. Revista de Administração } & \text { Pública, } & \text { 44(2), } & \text { 437-457. }\end{array}$ http://dx.doi.org/10.1590/S0034-76122010000200011

Lopez, F. G. (2004). A política cotidiana dos vereadores e as relações entre executivo e legislativo em âmbito municipal: O caso do município de Araruama. Revista de Sociologia e Política, (22), 153-177. http://dx.doi.org/10.1590/s0104-44782004000100012

Ministério da Previdência e Assistência Social (MPAS). (2011). A previdência. Retrieved April 05, 2014, from http://www.mpas.gov.br

MPS. (2014). Deficit da Previdência Social. Retrieved December 05, 2014, from http://www.previdencia.gov.br/noticias

Neter, J., Kutner, M., Wasserman, W., \& Nachtsheim, C. (1996). Applied linear statistical models. New York: McGraw-Hill.

Ogasavara, R. S. (1998). Previdência dos servidores públicos: Riscos e oportunidades. Brasília: Tesouro $\begin{array}{lllll}\text { Nacional. } & \text { Retrieved } & \text { December } & 05, & \text { 2014, }\end{array}$ 
http://www3.tesouro.fazenda.gov.br/Premio_TN/iiipremio/financas/MencaoHonrosa2topicosIII_PTN/OGA SAVARA_Roberto_Shoji.pdf

Paes de Paula, A. P. (2005). Administração Pública Brasileira Entre o Gerencialismo e a Gestão Social. RAE-Revista de Administração de Empresas, 45(1). Retrieved December 05, 2014, from http://rae.fgv.br/sites/rae.fgv.br/files/artigos/10.1590_S0034-75902005000100005.pdf

Pierre, J. (2005). Comparative public administration: The state of the art. Aldershot: Edward Elgar.

Raupp, F. M., \& Pinho, J. A. G. de. (2013). Accountability em câmaras municipais: Uma investigação em portais eletrônicos. Revista de Administração (São Paulo), 48(4), 770-782. Retrieved March 07, 2015, from http://www.scielo.br/scielo.php?script=sci_arttext\&pid=S0080-21072013000400011\&lng=en\&tlng=pt. 10.5700/rausp1120

Simão, E. (2010). Previdência de municípios corre risco de falência. Retrieved November 05, 2014, from http://www.estadao.com.br/noticias/impresso,previdencia-de-municipios-corre-risco-de-falencia,527476,0.h $\mathrm{tm}$

Stiglitz, J. E. T. (2000). The contributions of the economics of information to twentieth century economics. Quarterly Journal of Economics, 463, 1441-79. http://dx.doi.org/10.1162/003355300555015

Tafner, P., \& Giambiagi, F. (2007). Previdência no Brasil: Debates, dilemas e escolhas. Rio de Janeiro: IPEA.

Tavares, M. L., Ibrahim, F. Z. „\& Vieira, M. A. R. (2004). Comentários à reforma da previdência: EC no 41/2003. Rio de Janeiro: Impetus.

Vaz, L. R. (2009). O princípio do equilíbrio financeiro e atuarial no sistema previdenciário brasileiro. Revista Direitos Fundamentais e Democracia, 6, 4-35. Retrieved November 07, 2014, from http://revistaeletronicardfd.unibrasil.com.br/index.php/rdfd/article/view/240/234

Vilanova, W. (1969). Matemática atuarial. São Paulo: Livraria Pioneira Editora.

Zylberstajn, H., Zylberstajn, E., Afonso, L. E., \& Souza, A. P. (2008). Uma proposta para a criação de um sistema único de previdência social para o Brasil. Anais do Encontro da Associação Nacional de Pós-Graduação e Pesquisa em Administração, Rio de Janeiro, RJ. Brasil, 32. Retrieved December 05, 2014, from http://www.anpad.org.br/admin/pdf/APS-B324.pdf

Note

Note 1. CPA-10 is a professional certification granted by ANBIMA (Brazilian Association of Entities of Financial and Capital Markets).

\section{Copyrights}

Copyright for this article is retained by the author(s), with first publication rights granted to the journal.

This is an open-access article distributed under the terms and conditions of the Creative Commons Attribution license (http://creativecommons.org/licenses/by/3.0/). 